\title{
What Explains Variation In Segment Reporting? Evidence From Kuwait
}

Mishari M. Alfaraih, The Public Authority for Applied Education and Training, Kuwait

Faisal S. Alanezi, The Public Authority for Applied Education and Training, Kuwait

\begin{abstract}
The purpose of this study is to evaluate both the segment disclosure practice of firms listed on the Kuwait Stock Exchange (KSE) and the factors that influence their level of segment disclosures. Consistent with prior disclosure research, the level of segment disclosure is examined using a disclosure index based on the mandatory requirements of International Accounting Standard (IAS) 14 (Segment Reporting). The results show that the average level of segment disclosure in a sample of $123 \mathrm{KSE}$-listed firms in 2008 was $56 \% \%$, ranging from $18 \%$ to $94 \%$. Users of KSE-listed firms' financial statements might reasonably expect greater segment disclosures from larger, older, highly leveraged, and profitable KSE-listed firms, as well as from firms audited by a Big-4 audit firm. The findings provide feedback to the regulatory and enforcement bodies in Kuwait on current segment disclosure practice among KSE-listed companies and the factors that influence the level of segment disclosures. The noticeable variation in the level of segment disclosure among listed firms suggests a need for further monitoring of the enforcement of required segment disclosure.
\end{abstract}

Keywords: segment reporting; IAS 14; information disclosure; Kuwait

\section{INTRODUCTION}

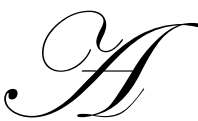

consolidated financial statement provides information about a firms overall profitability, risk, and growth potential. However, with the growing diversification and complexity of business enterprises, investors and investment analysts have sought more value-relevant information in order to make informed investment decisions. Investors and analysts need to understand how the various components of a diversified firm behave economically. It is difficult, if not impossible, for investors and analysts to predict the overall amounts, timing, and risks of a complete firm's future cash flows without desegregation, therefore segmental information is essential to investment analysis (AIMR, 1993). Berger and Hann (2002) argue that disaggregated information is extremely useful and important to financial statement users. A survey conducted by Epstein and Palepu (1999) of 140 star sell-side analysts reveals that most analysts consider segment-performance information to be the most useful for their investment decisions.

Recognizing the critical role of segmental information in helping investors make economic decisions, the International Accounting Standards Board (IASB) established the International Accounting Standard (IAS) 14 (Segment Reporting). The objective of IAS 14 is to establish principles for reporting financial information according to a firm's line of business and geographical area to help users of financial statements better understand a firm's past performance; this allows a better assessment of a firm's risks and returns; and provides users with sufficient information to make informed judgments about a firm as whole (IASB, 2008).

Prior research has highlighted a number of problem areas on segment reporting, however, particularly in managerial discretion in segment-information disclosure (Street et al., 2000). Prather-Kinsey and Meek (2004) argue that firms respond to segment-reporting disclosure but do not wholly embrace it, which results in substantial noncompliance. Birt et al. (2007) argue that the corporate failures involving the loss of hundreds of millions of dollars in Australia, the United States, and elsewhere that captured the world's attention in the early twenty-first century highlighted the vital role of disclosure and compliance. However, users of financial statements have long 
voiced concern about compliance with segment-reporting disclosures. While the literature investigates segmentreporting practice in developed markets, little attention has been given to emerging markets where the quality of accounting standards and their enforcement are questionable. Motivated by the lack of research on segmentreporting disclosures in Kuwait, the purpose of this study is to evaluate both the segment disclosure practice of firms listed on the Kuwait Stock Exchange (KSE) and the factors that influence their level of segment disclosures.

Following a review of the literature on disclosure, seven research hypotheses are developed and tested to address the influence of firm-specific attributes on the level of segment disclosures. It is hypothesized that the level of segment disclosure increases with firm size (H1), auditor type (H2), age (H3), ownership diffusion (H4), profitability (H5), and leverage (H6). It is predicted that the level of segment disclosure decreases as the firm grows (H6). Consistent with prior disclosure research, the level of segment disclosure is examined using a disclosure index based on the mandatory requirements of IAS 14. Descriptive statistics indicate that the average level of segment disclosure in a sample of $123 \mathrm{KSE}-$ listed companies in 2008 was $56 \%$, ranging from $18 \%$ to $94 \%$. A notable variation in the companies' levels of segment disclosure is observed in the study sample. This variation encourages an examination of the firm characteristics that affect the level of segment disclosure. A multiple regression model is used to determine which firm's characteristics are associated with segment disclosures. The findings indicate that firm size, auditor type, age, profitability, and leverage are significant factors in explaining the level of segment disclosure among KSE-listed firms. The results also show that ownership diffusion and growth are not significant factors in explaining the level of segment disclosure.

The findings of this study have implications for KSE regulators and the users of KSE-listed companies' financial statements. This study is the first to empirically investigate the determinants of segment disclosure practice among KSE-listed companies. The findings provide feedback to the regulatory bodies in Kuwait on current segment disclosure practice among KSE-listed companies and the factors that influence the level of segment disclosures. The noticeable variation in the level of segment disclosure among listed companies suggests a need for further monitoring of the enforcement of required segment disclosure. Users of KSE-listed companies' financial statements might reasonably expect greater segment disclosures from larger, older, highly leveraged, and profitable KSE-listed firms, as well as from firms audited by a Big-4 audit firm.

The remainder of the study is organized as follows. The next section discusses the financial reporting regulations in Kuwait. In Section 3, we review the literature and develop hypotheses on the corporate determinants of segment disclosures. Section 4 contains data and model details, the variables and the sample. In Section 5, we present the results of the study. Finally, in Section 6 we provide concluding remarks.

\section{FINANCIAL REPORTING REGULATIONS IN KUWAIT}

The growth of corporate activity and the rapid changes in the economic and commercial activities in Kuwait allowed the government to introduce regulations to handle the potential issues they spawned (Shuaib, 1978). Additionally, consistent with their western Anglo-American counterparts, separation of management and ownership is an explanation for increased demands for accounting information (Shuaib, 1978). Indeed, management of Kuwaiti companies likewise needed accounting information for making decisions in formulating their policies and in directing their operations. Also, it could be said that the Kuwaiti investors, creditors and Kuwait government agencies are interested in the financial information related to the financial positions and financial performances of the corporations in the country. Against that background the Kuwaiti government reacted to the demand for accounting information by issuing several laws and regulations.

Similar to most developing countries, the regulations of accounting in Kuwait are through a conventional framework of Commercial Companies Law. This law, considered the primary law, contains statutory accounting requirements about the Kuwaiti companies' affairs.

This Law provides only the basic requirements for disclosure and reporting applicable to all companies incorporated in Kuwait. The Commercial Companies Law No. 15/1960 requires that companies prepare an annual report, including a profit and loss account and balance sheet. Companies are required to provide shareholders with a copy of the balance sheet of the expired financial year, profit and loss account and the reports of both the directors 
and the auditor. Directors are required, within two months of the date of the Annual General Meeting to approve the accounts, publish in the official Gazette the balance sheet of the expired year and a list stating the names of the directors and the auditors. However, there are no further requirements concerning the form and content of the financial statements. It could be said that Law No. 15/1960 failed to indicate the actual level of information that a company should disclose. No particular formats were prescribed and even the necessary contents of the accounting reports were not specified.

Another law requires information related to financial reporting in Kuwait is Kuwait Commercial Law No. 68/1980 replaced No.2/1961. This law imposing limited and vague information requirements related to accounting aspects. Every company is required to maintain proper accounting records in accordance with generally accepted accounting principles, not themselves defined by law. Therefore, it is reasonable to conclude local corporate disclosure rules and regulations in Kuwait are relatively unsophisticated, comprise minimal disclosure requirements, though it might be considered that what they specified not inconsistent with the detail now set out in the IFRSs. Due to that, the Kuwaiti government decided to move toward full adoption of IAS/IFRS.

According to Belkaoui, (1994), the possible reasons for countries to move towards 'full adoption' of the IFRSs may be to reduce the setup and production costs, joining the international harmonisation drive, facilitating the growth of foreign investment, enable their accounting profession to emulate well-established professional standards of behaviour and conduct, and to legitimise its status as a full-fledged member of the international community. All arguably are consistent with the current state of Kuwait's development and would have had unquestionable appeal to its government. In 1990, the Ministry of Commerce and Industry issued Ministerial Resolution No. 18 of 1990. According to article 1 of the resolution, all companies in Kuwait, whatever their legal status, to prepare their financial statements in accordance with the IFRSs. This resolution placed Kuwait alongside a number of developed and developing countries, which have adopted the IFRSs. After adoption of the IFRSs, the level of the financial information disclose to users improved significantly.

Since all KSE-listed companies are legally required to comply with all IASs/IFRS, the focus of this study is to investigate the level of compliance with all the mandatory disclosures required by IAS 14. The objective of IAS 14 is to establish principles for reporting financial information by line of business and by geographical area. It applies to enterprises whose equity or debt securities are publicly traded and to enterprises in the process of issuing securities to the public. In addition, any enterprise voluntarily providing segment information should comply with the requirements of the Standard. If an enterprise that is not publicly traded chooses to report segment information and claims that its financial statements conform to IAS, then it must follow IAS 14 in full. Segment information need not be presented in the separate financial statements of a (a) parent, (b) subsidiary, (c) equity method associate, or (d) equity method joint venture that are presented in the same report as the consolidated statements (IASB, 2008).

\section{THEORETICAL FRAMEWORK AND HYPOTHESES DEVELOPMENT}

\subsection{The Theoretical Framework}

The influential works of Grossman (1981) and Milgrom (1981) delineate possible incentives for companies to provide full disclosure to investors. The authors argue that, in the absence of disclosure, investors must obtain and analyze data from other sources, and they incur costs while doing so. Due to a lack of information, investors lower the price they are willing to pay for a firm's stock. Companies are then motivated to disclose all relevant information to mitigate undervaluation. Thus, firms find it more beneficial to disclose additional information to investors. This argument is based on the notion that information asymmetry between companies and investors is created when firms do not fully disclose information (Petersen and Plenborg, 2006). According to economic theory, information asymmetry can increase a firm's capital cost because imperfect information can lead to "adverse selection" between buyers and sellers of a firm's securities. This adverse selection tends to reduce the liquidity of a firm's securities (Copeland and Galai, 1983; Glosten and Milgrom, 1985).

In contrast, increased disclosure improves investors' ability to compare firms and permits them to recognize and choose more efficient firms. Thus, in the absence of full disclosure, firms must discount share issues to provide extra compensation to potential investors who may be hesitant to hold shares in firms that offer limited 
liquidity. Because of the discount, the firm receives less capital from the issue of equity, ultimately increasing the firm's capital cost. By increasing their disclosures, firms are likely to mitigate the information asymmetry between firms and investors, which should reduce capital costs (Diamond and Verrecchia, 1991). The reduction in capital costs motivates firms to disclose information in their reports to attract investors and maintain low capital costs. Although previous studies have documented the benefit associated with greater disclosure, such as reducing equity capital and debt costs, Verrecchia (1983) contends the benefits of disclosure are limited by a "proprietary cost." Scott (1994) defines "proprietary cost" as any possible reduction in future cash flows that are attributable to disclosure. Verrecchia (1983) argues that the release of more information about a firm, either favorable or unfavorable, is useful to competitors, investors, and employees in ways that could threaten the firm's prospects and competitive position. This could cause reductions in future cash flows. This potential threat associated with disclosure may cause firms to limit their disclosure levels when proprietary costs arise. Healy and Palepu (2001) document that, when proprietary costs arise, companies have an incentive not to disclose information that could weaken their competitive position, even if not disclosing information increases the cost of raising additional equity; in other words, there is a cost-benefit trade-off.

\subsection{Corporate Determinants Of Segment Disclosures}

Several disclosure studies explore the relationship between the level of segment disclosure and various corporate characteristics, such as, size, profitability, growth, ownership diffusion, audit quality, leverage, or age. For example, Kevin and Zain (2001) examine the relationship between the extent of segment disclosure and four firm characteristics: size, financial leverage, proportion of assets in place, and earnings volatility. Their findings indicate that only firm size and proportion of assets in place are significant determinants of segment disclosure. Similarly, Prencipe (2004), using the proprietary cost theory, shows that firm age, size, growth rate, listing status, ownership diffusion, and leverage are significant determinants of the extent of segment disclosure. Furthermore, Abu-Serdaneh and Zuriekat (2009) investigate the extent of segment reporting in Jordanian companies and the corporate characteristics that affect the level of segment disclosure. Their study shows that companies that have disclosed more segmental information are larger, have less ownership diffusion, and a higher assets-in-place percentage.

\subsection{Hypothesis Development}

The literature pertinent to disclosure highlights the effects of firm-specific characteristics on a firm's disclosure level. To investigate the determinants of segment disclosures among firms listed on the KSE, this study examines seven firm attributes identified in previous studies as significant factors that affect disclosure levels.

Numerous disclosure studies have suggested that larger firms tend to disclose more information in annual reports than smaller firms. In their review of disclosure and determinants studies, Chavent et al. (2006) identify three reasons for a positive relationship between firm size and disclosure level. First, larger firms are more politically visible than smaller firms. As a result, they are exposed to more litigation and government intervention. Therefore, larger firms are more willing to disclose information to reduce political costs and mitigate litigation and government intervention. Second, the cost of accumulating information is lower for larger firms because of their extensive internal reporting systems. Third, smaller firms are more likely to conceal sensitive information because full disclosure may jeopardize their competitive positions. Watts and Zimmerman (1983) argue that agency costs are higher for larger firms due to the larger number of shareholders. As a result, managers of large firms have an incentive to reduce potential agency costs. One way to do that is by disclosing more accounting information. Thus, it is hypothesized that

\section{H1: The level of segment disclosure is positively associated with a firm's size.}

The relationship between a firm's disclosure level and the size of its external auditing firms is well established in the disclosure literature (Palmer, 2008). A positive relationship between disclosure level and the quality of external audit has been reported in several studies. The literature has provided several justifications for this association. DeAngelo (1981) argues that larger auditing firms have well-established reputations and, therefore, have more to lose if they fail to report a discovered breach or make errors or misrepresentations in their clients' corporate reports. Malone et al. (1993) argue that smaller auditing firms are sensitive to their clients' demands 
because of the economic consequences of losing a client. Wallace and Naser (1995) claim that, due to this sensitivity phenomena, larger auditing firms are less likely to depend on one or a few clients. The apparent lack of bonding with clients enables larger auditing firms to demand greater disclosure in their clients' corporate annual reports (Wallace and Naser, 1995).Wallace et al. (1994) argue that firms audited by internationally affiliated auditing firms (Big-4) are more likely to provide more detailed information than firms audited by local auditing firms. The rationale is that internationally affiliated auditing firms tend to be larger and offer more expertise than local auditing firms. Accordingly, it is hypothesised that

\section{H2: The level of segment disclosure is positively associated with being audited by a Big-4 auditing firm.}

Firm age, or the number of years since a firm's foundation, may affect a firm's level of disclosures. In comparing older and younger firms, Glaum and Street (2003) argue that younger firms tend to concentrate on product and market development rather than accounting when establishing their businesses. In addition, managers of younger firms tend to be less experienced in running a listed corporation and complying with regulatory requirements. Consequently, Glaum and Street (2003) contend that younger firms' accounting systems tend to be inadequate, resulting in lower-quality accounting and disclosures. In contrast, older firms tend to have wellestablished accounting systems and experienced managers and staff, resulting in higher-quality accounting and disclosures. In addition, a possible competitive disadvantage exists for younger firms who disclose more information on line of business or by geographical area of business. This disadvantage would arise if competitors were to use disclosed information to the detriment of younger firms. In contrast, older firms might be more motivated to disclose such information because it would be less likely to harm their competitive positions (Owusu-Ansah, 1998; AlSammari, 2005). Due to the large variation in the ages of KSE-listed firms, it is expected that older KSE firms will be more likely to comply with IFRS-required disclosures than younger KSE firms. Therefore, it is hypothesized that

\section{H3: The level of segment disclosure is positively associated with a firm's age.}

Ownership diffusion, measured as the ratio of the number of shares owned by outsiders to the number of outstanding shares, has been identified in previous studies as a factor that affects disclosure levels. Agency theory is used to explain the behavior of principals (shareholders) and agents (managers) in the separation of ownership and firm control. The theory explains problems that arise when shareholders rely on managers to provide services on their behalf, which are due to the separation of ownership and control (Jensen and Meckling, 1976). If parties act in self-interest, the conflict of interest between shareholders and managers increases. Due to these interest conflicts, agency costs rise. Managers have an incentive to reduce these agency costs, and one way to do so is to disclose more accounting information (Morris, 1987). Thus, a positive relationship is expected to be found between ownership diffusion and the level of segment disclosure

\section{H4: The level of segment disclosure is positively associated with a firm's ownership diffusion.}

Singhvi and Desai (1971) claim that managers are more likely to disclose detailed information when profitability is high to signal their ability to maximize shareholders' value, increase the security of their positions, and justify their compensation. In addition, managers of profitable firms may feel proud of their success and disclose more information to the public to promote a positive impression of their performance (Alsaeed, 2006). On the other hand, a firm may disclose less information when profitability is low to hide the various reasons for declining profitability or even losses. Thus, firms with high profitability would be expected to disclose more information than firms with low profitability (Singhvi and Desai, 1971). Using agency and signalling theories, Inchausti (1997) claims that when managers possess "good news" due to better performance, they disclose more detailed information to the market than when they possess "bad news," to prevent their shares from being undervalued. Consequently, it is hypothesized that

\section{H5: The level of segment disclosures is positively associated with a firm's profitability.}

Several previous studies have explored the relationship between disclosure levels and firm leverage. Firms with high leverage are generally expected to disclose more information to satisfy creditors (Alsaeed, 2006). In 
disclosure literature, the agency theory is used to explain the incentive for managers of high-leverage firms to provide more disclosure (Morris, 1987). Alsaeed (2006) argues that firms with proportionally higher levels of debt in their capital structure are prone to higher agency costs. Therefore, managers have an incentive to reduce these agency costs. One method is to disclose more accounting information to satisfy the needs of debenture holders (Morris, 1987). In addition, by disclosing more information, highly leveraged firms can assure creditors that they are less likely to bypass their covenant claims (Ali et al., 2004). Similarly, Wallace et al. (1994) argue that highleverage firms have a greater obligation to satisfy the informational needs of their long-term creditors and, thus, may provide more detailed information in their annual reports than low-leverage firms. Consequently, it is hypothesized that

H6: The level of segment disclosure is positively associated with a firm's leverage.

In their review of disclosure and determinants studies, Chavent et al. (2006) found that growing firms are more likely to conceal sensitive information, because full disclosure may jeopardize their competitive positions. Similarly, Prencipe (2004) argues that the potential competitive costs arising from disclosing segment information tend to be particularly high for growing firms, as competitors could use this information to the detriment of growing firms. Thus, a negative relationship between a firm's growth and level of segment disclosure is expected to be found. Consequently, it is hypothesized that

H7: The level of segment disclosures is negatively associated with a firm's growth.

\section{RESEARCH DESIGN AND METHOD}

\subsection{Population, Sample, And Data Collection}

Since all companies operating on the KSE must comply with IAS 14 disclosure requirements in accordance with Resolution No. 18 of 1990, the population of this study for measuring segment disclosure consists of all the companies listed on the KSE in 2008. The KSE's Investor Guide for 2008 shows that, by the end of 2008, the KSE listed 189 Kuwaiti companies. However, it should be noted that not all KSE companies are diversified and, therefore, some companies are not relevant to this study. Thus, the selection of companies in the sample is based on the applicability of segment disclosure requirements to the firm. That is, firms that can be segmented into business lines or geographical areas are included in the study sample. After employing this criterion to the entire population, the sample consists of $123 \mathrm{KSE}$-listed companies. All the financial statements for KSE-listed companies were obtained from the Auto Documentation and Archival Department at the KSE. Table 1 shows the industry classification of sample companies and their percentages relative to the entire sample population.

Table 1: Number Of Companies At The End Of 2008 And The Sample Size

\begin{tabular}{|c|c|c|c|}
\hline Industry Classification & $\begin{array}{c}\text { No. of Companies at the } \\
\text { End of 2008 }\end{array}$ & $\begin{array}{c}\text { No. of Companies in the } \\
\text { Sample }\end{array}$ & $\mathbf{\%}$ \\
\hline $\begin{array}{c}\text { Financial } \\
\text { (Banks and Insurance) }\end{array}$ & 16 & 15 & $12 \%$ \\
\hline Investment & 46 & 39 & $32 \%$ \\
\hline Real Estate & 36 & 20 & $16 \%$ \\
\hline $\begin{array}{c}\text { Industrial } \\
\text { (Industry and Food) }\end{array}$ & 34 & 28 & $23 \%$ \\
\hline Service & 57 & 21 & $17 \%$ \\
\hline Total & 189 & 123 & $100 \%$ \\
\hline
\end{tabular}

\subsection{Measuring the Extent Of Segment Disclosure}

The dependent variable in this study is the level of segment disclosure. A Segment Disclosure Index (SDI) was developed based on IAS 14 mandatory requirements. In constructing and developing the SDI, the official IASB volume for 2008 (IASB, 2008) is used to obtain details about IAS 14 requirements. The SDI is constructed to 
specifically address the mandatory disclosure requirements of IAS 14. Disclosures that are explicitly voluntary or merely encouraged are not included in the SDI. From IAS 14, 28 mandatory disclosure requirements are obtained and set out in the constructed SDI (Appendix A). Following prior studies on scoring the index (Tower et al., 1999; Street and Bryant, 2000; Street and Gray, 2002; Haniffa and Cooke, 2002; Glaum and Street, 2003; Ali et al., 2004; Al-Shammari et al., 2008), an item of information was assigned " 1 " if it is clearly disclosed, " 0 " if it is clearly not, and the conventional "N/A" if it is clearly not applicable.

\subsection{Determinants Of Segment Disclosures}

Specific firm characteristics are used as determinants of segment disclosures in this study. Information regarding firm age, industry categories, and ownership diffusion were obtained from the official KSE's Web site. Data related to firm size, audit quality, profitability, leverage, and growth were extracted from the companies' financial statements. Table 2 presents definitions of all specific company characteristics used in this study as determinants of segment disclosures.

Table 2: Definition Of Firm Characteristics (Independent Variables)

\begin{tabular}{|c|l|}
\hline $\begin{array}{c}\text { Independent } \\
\text { Variable }\end{array}$ & \multicolumn{1}{c|}{ Operationalization } \\
\hline Company size & The log of total assets \\
\hline Audit quality & Dummy variable coded 1 if one Big-4 audit firm audits the company's financial statements and 0 otherwise \\
\hline Company age & Number of years passed since incorporated \\
\hline $\begin{array}{c}\text { Ownership } \\
\text { diffusion }\end{array}$ & Number of shares owned by outsiders / number of outstanding shares at year-end \\
\hline Profitability & Return on equity (ROE) \\
\hline Leverage & Total debt / total shareholders equity \\
\hline Growth & The growth in sales over the previous fiscal year \\
\hline Industry & $\begin{array}{l}\text { Dummy variable that equals 1 for firms in the financial institutions category and 0 otherwise; dummy variable } \\
\text { that equals } 1 \text { for firms in the investment category and } 0 \text { otherwise; dummy variable that equals } 1 \text { for firms in } \\
\text { the industrial category and } 0 \text { otherwise; dummy variable that equals } 1 \text { for firms in the service category and } 0 \\
\text { otherwise }\end{array}$ \\
\hline
\end{tabular}

\subsection{Model Specification}

After determining the level of segment disclosures, the next step is to investigate the relationship between the level of segment disclosures and the firm's characteristics to explain why firms differ in their level of segment disclosures. A multiple regression model is used to determine which firm characteristics are associated with segment disclosures. Thus, the following regression model was fitted to the data:

$\mathrm{Y}=\beta_{0}+\beta_{1}$ (company size) $+\beta_{2}$ (audit quality) $+\beta_{3}$ (company age $)+\beta_{4}$ (ownership diffusion) + $\beta_{5}$ (profitability) $+\beta_{6}$ (leverage $)+\beta_{7}$ (growth) $+\beta_{8-11}$ (industry $\left.1-4\right)+\varepsilon$

where, $\mathrm{Y}=$ segment disclosure score; $\beta_{0}=$ regression intercept, the other ${ }^{\beta} \mathrm{s}$ are the parameters of the Model.

\section{RESULTS}

\subsection{Descriptive Statistics}

Table 3 presents descriptive statistics for Segment Disclosure Index (SDI). The table shows that the mean for the SDI of a sample of KSE-listed companies in 2008 was 0.56 , with a minimum score of 0.18 and a maximum of 0.94 . These results suggest that disclosure levels among the 123 sample companies were widely distributed. A notable variation in firms' levels of segment disclosure is observed in the study sample. This variation encourages an examination of the company characteristics that affect the level of segment disclosure. 
Table 3: Descriptive Statistics For The Segment Disclosure Index (Sdi)

\begin{tabular}{|c|c|c|c|c|c|}
\hline Dependent Variable & $\mathbf{N}$ & Mean & Min & Max & Standard Deviation \\
\hline SDI & 123 & 0.56 & 0.18 & 0.94 & 0.22 \\
\hline SDI = Segment Disclosure Index
\end{tabular}

Table 4 presents the descriptive statistics for the independent continuous and dummy variables used in this study. A significant degree of variation exists in firm size as shown in Panel A. Firm size ranges from KD 5.46 million to KD 11973.23 million, with a mean of 411.03 million and a median of 100.23 million. Due to the nonnormality, firm size was transformed using the natural logarithm of total assets as of December 31, 2008, as shown in the variable LSIZE. In addition, Panel A of Table 4 shows that the age of firms examined in this study ranged from 4 to 57 years, with a mean of 26 years and a median of 27 years. Ownership diffusion ranges from 0 to 0.96 , with a mean of 0.55 and firm profitability varies from -0.58 to 0.48 , with a mean of 0.07 . In addition, the descriptive statistics presented in Panel A shows that firm leverage ranges from 0.01 to 0.98 , with a mean of 0.43 , and firm growth range from -0.97 to 5.17 , with a mean of 0.20 . Panel B of Table 4 presents the distribution of firms that were audited by Big- 4 and non-Big-4 audit firms. The results reveal that $59 \%$ of the firms included in the study were audited by Big-4 audit firms, while $41 \%$ of the firms were audited by non-Big- 4 audit firms. Table 5 shows colinearity diagnostic statistics based on the Variance Inflation Factor (VIF) test. The VIF values presented in Table 5 do not raise concern regarding multicolinearity among variables because all variables had low VIF values. The VIF value for each independent variable is way below the suggested VIF of 10 (Belsley et al., 1980; Neter et al., 1989). Consequently, multicolinearity did not appear to be a serious problem in interpreting the regression results of this study.

Table 4: Descriptive Statistics For Independent Continuous And Dummy Variables

\begin{tabular}{|c|c|c|c|c|c|}
\hline $\begin{array}{c}\text { Panel A: } \\
\text { Independent Variable }\end{array}$ & Mean & Median & $\begin{array}{l}\text { Standard } \\
\text { Deviation }\end{array}$ & Minimum & Maximum \\
\hline SIZE & 411.03 & 100.23 & 1082.70 & 5.46 & 11973.32 \\
\hline LSIZE & 11.55 & 11.51 & 1.48 & 8.61 & 15.66 \\
\hline AGE & 25.80 & 27.00 & 13.06 & 4.00 & 57.00 \\
\hline OWNERSHIP & 0.55 & 0.57 & 0.22 & 0 & 0.96 \\
\hline PROFIT & 0.07 & 0.08 & 0.11 & -0.58 & 0.48 \\
\hline LEVERAGE & 0.43 & 0.46 & 0.28 & 0.01 & 0.98 \\
\hline GROWTH & 0.20 & 0.12 & 0.78 & -0.97 & 5.17 \\
\hline $\begin{array}{c}\text { Panel B: } \\
\text { Dummy Variable }\end{array}$ & Frequency & Percent & & & \\
\hline \multicolumn{6}{|l|}{ Auditor Quality } \\
\hline Non-Big-4 & 51 & 41 & & & \\
\hline Big-4 & 72 & 59 & & & \\
\hline Total & 123 & 100 & & & \\
\hline
\end{tabular}

SIZE is the amount of firms' total assets (KD million) at the end of 2008; LSIZE is the natural logarithm of total assets at the end of 2008; AGE is the number of years passed since foundation to the end of 2008; OWNERSHIP diffusion is measured by number of shares owned by outsiders / number of outstanding shares at year-end; PROFIT is the Return on Equity (ROE) for the year ended 31 December, which is the ratio of net income to average common shareholders' equity; LEVERAGE is the ratio of total debt to total shareholders' equity at the end of 2008, and GROWTH is the growth in sales over the previous fiscal year. 
Table 5: Colinearity Statistics

\begin{tabular}{|c|c|c|}
\hline Independent Variable & Tolerance & VIF \\
\hline LSIZE & 0.471 & 2.124 \\
\hline AGE & 0.789 & 1.267 \\
\hline OWNERSHIP & 0.776 & 1.289 \\
\hline PROFITABILITY & 0.941 & 1.063 \\
\hline LEVERAGE & 0.561 & 1.782 \\
\hline GROWTH & 0.901 & 1.110 \\
\hline
\end{tabular}

\subsection{Regression Analysis}

Table 6 provides the results of the multiple regression model. The results of the multiple regression reveal that the regression model, which attempts to explain variation in the segment disclosure level in term of firm attributes, is highly significant $(F=5.237, p<0.000)$. The adjusted $R^{2}$ of the multiple regression model indicates that company attributes considered in this study explain $23 \%$ of the variation in segment disclosures. Consistent with hypothesis 1 (H1), Table 6 shows that firm size (LSIZE) is a significant factor in explaining the variations in segment disclosure levels among KSE-listed firms $(p<0.01)$. This result supports the argument that larger firms are more willing to disclose information to reduce political costs and mitigate litigation and government intervention. In addition, the cost associated with accumulating information is lower for larger firms because of their extensive internal reporting systems. In comparison, smaller firms are more likely to conceal sensitive information because full disclosure could jeopardize their competitive positions (Chavent et al., 2006). This result confirms prior disclosure research that suggests a positive relationship between firm size and information disclosure (Ali et al., 2004; Chavent et al., 2006; Gallery et al., 2008).

As predicted in hypothesis 2 (H2), the results in Table 6 show that the auditor type (AUDIT) is a significant factor in explaining variations in the level of segment disclosures $(p<0.05)$. This finding suggests that KSE firms that are audited by a Big-4 auditing firm tend to have a higher level of segment disclosures than firms audited by a non-Big-4 auditing firm. This result confirms the notion of Wallace et al. (1994) that firms audited by internationally affiliated audit firms - the Big-4 - are more likely to provide more detailed information than are firms audited by local audit firms. This is because the internationally affiliated audit firms are larger and backed by more expertise than are local audit firms (Wallace et al., 1994).

Hypothesis $3(\mathrm{H} 3)$ predicts that the level of segment disclosures is positively associated with firm age (AGE). Table 6 shows this to be the case $(p<0.01)$. Thus, older KSE-listed firms, because of their maturity and associated learning experience, are more likely to have well-established accounting procedures that produce more detailed information than younger KSE firms. Owusu-Ansah (1998) and Glaum and Street (2003) note that having well-established accounting systems can reduce costs and increase the ease of gathering, processing, and disseminating the information needed to comply with required disclosures. Another possible explanation for the significant, positive association between firm age and disclosure level is the potential competitive disadvantage to younger firms in disclosing more information according to their line of business or geographical area of business. Competitors could use this information to the detriment of younger firms. In contrast, older firms might be more motivated to disclose such information because doing so would be less likely to harm their competitive position (Owusu-Ansah, 1998). 
Table 6: Multivariate Regression Analysis Results

$\mathrm{SDI}=\beta_{0}+\beta_{1}$ (company size) $+\beta_{2}$ (audit quality) $+\beta_{3}$ (company age) $+\beta_{4}$ (ownership diffusion) $+\beta_{5}$ (profitability) $+\beta_{6}$ (leverage $)+\beta_{7}$ (growth) $+\beta_{8-11}\left(\right.$ industry $_{1-4)}+\varepsilon$

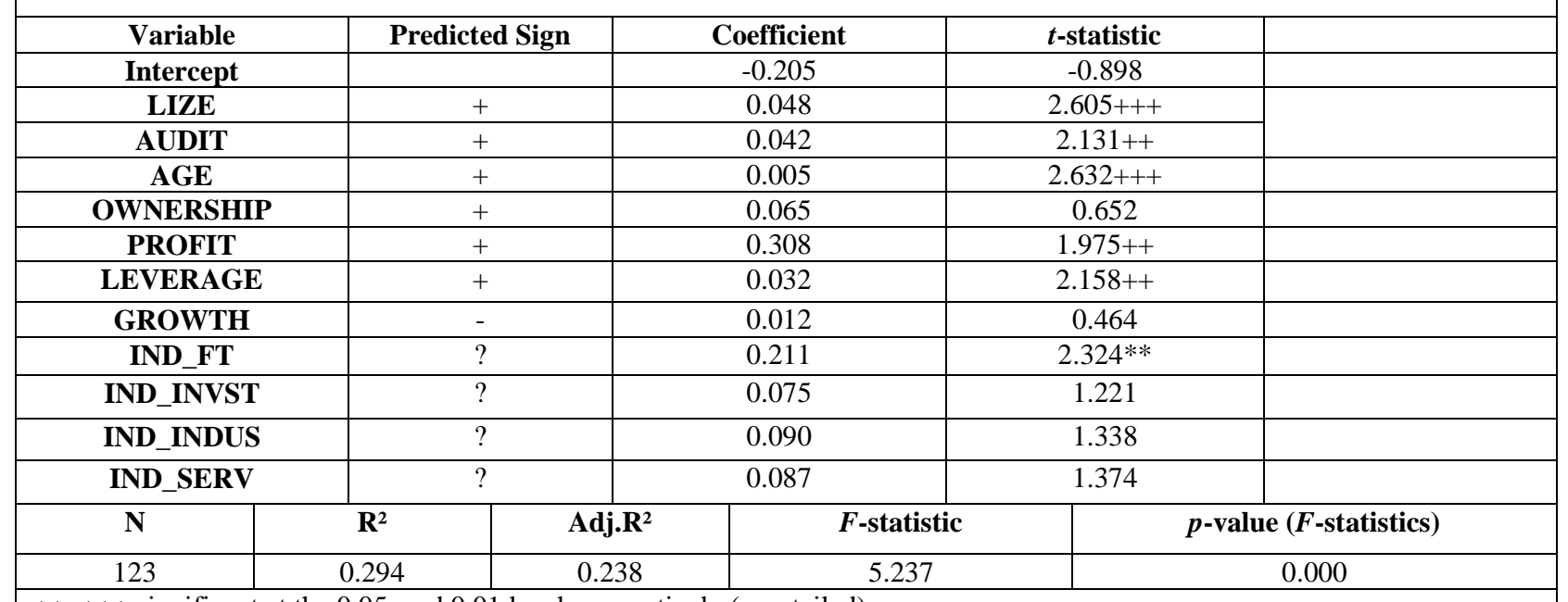

,+++++ significant at the 0.05 , and 0.01 levels respectively (one-tailed)

** significant at the 0.05 level (two-tailed)

SDI is the ratio of a firm's actual segment disclosure score to the maximum segment score that the firm is expected to achieve if the firm fully complies with the mandatory segment disclosure requirements of the IAS 14; LSIZE is the natural logarithm of total assets at the end of 2008; AUDIT is a dummy variable coded 1 if one Big-4 audit firm audits the firm's financial statements and 0 otherwise

; AGE is the number of years passed since foundation to the end of 2008; OWNERSHIP diffusion is measured by number of shares owned by outsiders / number of outstanding shares at year-end; PROFIT is the Return on Equity (ROE) for the year ended 31 December, which is the ratio of net income to average common shareholders' equity; LEVERAGE is the ratio of total debt to total shareholders' equity at the end of 2008 and GROWTH is the growth in sales over the previous fiscal year; IND_FT is a dummy variable that equals 1 for firms in the Financial Institutions category, and 0 otherwise; IND_INVST is a dummy variable that equals 1 for firms in the Investment category, and 0 otherwise; IND_INDUS is a dummy variable that equals 1 for firms in the Industrial category, and 0 otherwise; IND_SERV is a dummy variable that equals 1 for firms in the Service category, and 0 otherwise (the omitted industry category when all categories are 0 is the Real Estate category).

Consistent with hypothesis 5 (H5), the results in Table 6 show that the level of segment disclosures is positively and significantly associated with firm profitability (PROFIT) $(p<0.01)$. This finding supports the argument that managers are more likely to disclose detailed information when profitability is high to signal their ability to maximize shareholders' value and to avoid share undervaluation. This way they increase the security of their positions and justify their compensation. On the other hand, firms may disclose less information when profitability is low to hide the various reasons for declining profitability or losses (Singhvi and Desai, 1971; Inchausti, 1997). In support of hypothesis 6 (H6), Table 6 shows that the level of segment disclosure is positively and significantly associated with firm leverage $(p<0.05)$. This result is consistent with the notion that highly geared companies have a greater need to reduce agency costs and satisfy the information needs of long-term creditors; thus, they provide more detailed information in their annual reports to meet those needs than lower-geared companies (Morris, 1987; Wallace et al., 1994).

In contrast, an insignificant positive association is observed for ownership diffusion. Thus, hypothesis 4 (H4), that segment disclosure is positively associated with firm leverage, is not supported. Similarly, firm growth is found to be insignificantly associated with segment disclosure. Thus, hypothesis 7 (H7), that segment disclosure is negatively associated with firm growth, is not supported. Industry categories were used as control variables. For control variables, the results show that industry categories (except the financial sector) do not significantly influence segment disclosures. One possible reason could be because firms operating in the financial sector tend to have solid infrastructure and information systems that enable them to gather and process information easily. 


\section{CONCLUSIONS AND IMPLICATIONS}

The objective of the study is to evaluate the segment disclosure practice of KSE-listed firms as well as the factors that influence the level of segment disclosure. The existing theoretical literature on disclosure has used the capital need theory, agency theory, and signalling theory to provide possible motives for firms' financial reporting disclosure and to explain variations in the level of financial reporting disclosure across firms. In general, these studies show that firms might benefit from giving investors additional accounting information to exploit the disclosure benefits that exceed disclosure costs, such as lower capital or debt cost. In addition, several disclosure studies explore the relationship between the level of segment disclosure and several corporate characteristics, such as size, profitability, growth, ownership diffusion, audit quality, leverage, and age.

The literature pertinent to disclosure highlights the effects of specific firm characteristics on a firm's disclosure level. To investigate the determinants of segment disclosures, this study examines seven firm attributes identified in previous studies as significant factors affecting disclosure levels. It is hypothesized that the level of segment disclosure increases with firm size, auditor type, age, ownership diffusion, profitability, and leverage. It is predicted that the level of segment disclosure will decrease with firm growth. Consistent with prior disclosure research, the level of segment disclosure is examined using a disclosure index based on the mandatory requirements of the IAS 14. Descriptive statistics indicate that the average level of segment disclosure in the sample of $123 \mathrm{KSE}$ listed firm in 2008 was $56 \%$, ranging from $18 \%$ to $94 \%$. A notable variation in the firms' levels of segment disclosure is observed in the study sample. This variation encourages an examination of company characteristics that affect the level of segment disclosure. A multiple regression model is used to determine which company characteristics are associated with segment disclosures. The findings indicate that firm size, auditor type, age, profitability, and leverage are significant factors in explaining the level of segment disclosure among KSE listed firms. In contrast, the results show that ownership diffusion and growth are not significant factors in explaining the level of segment disclosure.

This study contributes by providing an assessment of the level of segment disclosure among KSE-listed companies and the factors that influence the extent of segment disclosure. The findings of this study provide some feedback to the regulatory and enforcement bodies in Kuwait about the current segment disclosure practice of KSElisted firms and the factors that influence the level of segment disclosures. The noticeable variation in the level of segment disclosure across listed firms suggests a need for further monitoring of the enforcement of required segment disclosure. In addition, users of KSE-listed firms' financial statements might reasonably expect greater segment disclosures from larger, older, highly leveraged, and profitable KSE-listed firms, as well as from firms audited by a Big-4 audit firm.

This study has limitations. First, the conclusions drawn are subject to an unavoidably small sample size as the KSE is a relatively small market. Second, the subjectivity inherent in scoring the segment disclosures is a concern in this and previous disclosure studies. However, consistent with previous well-known disclosure studies, several approaches were undertaken to minimize and overcome this potential bias and uncertainty in determining firm segment disclosure scores. Third, the possibility always exists that the study may have omitted other factors that would help explain this variation, such as corporate governance quality. Despite these limitations, this study contributes to the existing knowledge in the area of the segment reporting. This study has been a cross-sectional examination. How the current pattern of disclosure will change over time is contestable, but clearly a longitudinal study will be needed in due course to obtain a fuller understanding of the determinants of segment disclosure. In addition, it would be interesting to investigate the currently enforced IFRS 8 (Operating Segments) that replace IAS 14 and examine whether segment disclosures have improved with the introduction of IFRS 8.

\section{ABOUT THE AUTHORS}

Mishari M. Alfaraih, Ph.D., CPA, CIA is an Assistant Professors of Accounting at the College of Business Studies, The Public Authority for Applied Education and Training, Kuwait. He holds a Ph.D. in Accounting from Queensland University of Technology, Australia. He is a certified public accountant and a certified internal auditor. His research interests include financial information flows and information quality in capital markets. E-mail address: m@alfaraih.com. Tel: +965-99755666. 
Faisal S. Alanezi, Ph.D., is an Assistant Professors of Accounting at the College of Business Studies, The Public Authority for Applied Education and Training, Kuwait. He holds a Ph.D. in Accounting from University of Newcastle, Australia. His research interests include financial reporting and disclosure. E-mail address: alanezifs@ hotmail.com.Tel: +965-99133230.

\section{REFERENCES}

1. Abu-Serdaneh, J., \& Zuriekat, M. (2009). Segment Reporting in Jordanian Listed Companies. Arab Journal of Administrative Sciences, 16(3), 489-516.

2. Al-Shammari, B. (2005). Compliance with International Accounting Standards by Listed Companies in the Gulf Co-Operation Council Member States: An Empirical Study. Unpublished PhD Thesis, The University of Western Australia

3. Ali, M., Ahmed, K., \& Henry, D. (2004). Disclosure compliance with national accounting standards by listed companies in South Asia. Accounting and Business Research, 34(3), 183.

4. Alsaeed, K. (2006). The association between firm-specific characteristics and disclosure. Managerial Auditing Journal, 21(5), 476.

5. Association for Investment Management and Research (AIMR). (1993). Financial Reporting in 1990s and Beyond: A Position Paper of the Association for Investment Management and Research. Financial Accounting Policy Committee,Prepared by Peter H. Knuston. Charlottesville, VA: AIMR

6. Belkaoui, A. (1994). Accounting in the Developing Countries: Quorum Books, U.S.A.

7. Belsley, D., Kuh, E., \& Welsch, R. (1980). Regression Diagnostics: Identification Influential Data and Sources of Collinearity, New York: John Wiley \& Sons, Inc.

8. Berger, P., \& Hann, R. (2003). The Impact of SFAS No. 131 on Information and Monitoring. Journal of Accounting Research, 41(2), 163-163-223.

9. Birt, J., Kend, M., \& Xian, H. (2007). Changes in Segment Reporting in the Australian Banking Industry. Australian Accounting Review, 17(3), 61-61-67.

10. Chavent, M., Ding, Y., Fu, L., Stolowy, H., \& Wang, H. (2006). Disclosure and determinants studies: An extension using the Divisive Clustering Method (DIV). European Accounting Review, 15(2), 181.

11. Copeland, T. E., \& Galai, D. (1983). Information Effects on the Bid-Ask Spread. The Journal of Finance, 38(5), 1457.

12. DeAngelo, L. (1981). Auditor Size and Audit Quality. Journal of Accounting and Economics, 3(3), 183199.

13. Diamond, D. W., \& Verrecchia, R. E. (1991). Disclosure, Liquidity, and the Cost of Capital. The Journal of Finance, 46(4), 1325.

14. Epstein, M., \& Palepu, K. (1999). What financial analysts want. Strategic Finance, 80(10), 48-48-52.

15. Gallery.G, Cooper, E., \& Sweeting, J. (2008). Corporate Disclosure Quality: Lessons from Australian Companies on the Impact of Adopting International Financial Reporting Standards. Australian Accounting Review, 18(3), 257.

16. Glaum, M., \& Street, D. L. (2003). Compliance with the Disclosure Requirements of Germany's New Market: IAS Versus US GAAP. [Article]. Journal of International Financial Management \& Accounting, 14(1), 64-100.

17. Glosten, L. R., \& Milgrom, P. R. (1985). Bid, Ask and Transaction Prices in a Specialist Market with Heterogeneously Informed Traders. Journal of Financial Economics, 14(1), 71.

18. Grossman, S. (1981). The Role of Warranties and Private Disclosure about Product Quality. Journal of Law and Economics, 24(3), 461-483.

19. Haniffa, R. M., \& Cooke, T. E. (2002). Culture, corporate governance and disclousure in Malaysian corporations. Abacus, 38(3), 317.

20. Healy, P., \& Palepu, K. (2001). Information asymmetry, corporate disclosure, and the capital markets: A review of the empirical disclosure literature. Journal of Accounting \& Economics, 31(1-3), 405.

21. IASB. (2008). International Financial Reporting Standards Incorporating International Accounting Standards and Interpretations (London: International Accounting Standards Board)

22. Inchausti, B. (1997). The influence of company characteristics and accounting regulation on information disclosed by Spanish firms. The European Accounting Review, 6(1), 45-68. 
23. Jensen, M., \& Meckling, W. (1976). Theory of the Firm: Managerial Behavior, Agency Costs and Ownership Structure Journal of Financial Economics, 3(3), 305-360.

24. Kevin, L., \& Zain, M. (2001). Segmental Reporting: An Insight Into Malaysia's Companies. SSRN eLibrary.

25. KSE. (2008). KSE (2008). Investor guide. Kuwait Stock Exchange Bulletins.

26. Malone, D., Fries, C., \& Jones, T. (1993). An empirical investigation of the extent of corporate financial disclosure in the oil and gas industry. Journal of Accounting, Auditing \& Finance, 8(3), 249.

27. Milgrom, P. R. (1981). Good News and Bad News: Representation Theorems and Applications. Bell Journal of Economics, 12(2), 380.

28. Morris, R. D. (1987). Signalling, Agency Theory And Accounting Policy Choice. Accounting and Business Research, 18(69), 47.

29. Neter, J., Kutner, M. H., Nachtscheim, C. J., \& Wasserman, W. (1996). Applied Linear Statistical Models. Boston, MA: McGraw-Hill.

30. Owusu-Ansah, S. (1998). The impact of corporate attributes on the extent of mandatory disclosure and reporting by listed companies in Zimbabwe. The International Journal of Accounting, 33(5), 605.

31. Palmer, P. (2008). Disclosure of the impacts of adopting Australian equivalents of International Financial Reporting Standards. Accounting \& Finance, 48(5), 847-870.

32. Petersen, C., \& Plenborg, T. (2006). Voluntary disclosure and information asymmetry in Denmark. Journal of International Accounting Auditing \& Taxation, 15(2), 127.

33. Prather-Kinsey, J., \& Meek, G. (2004). The effect of revised IAS 14 on segment reporting by IAS companies. European Accounting Review, 13(2), 213.

34. Prencipe, A. (2004). Proprietary costs and determinants of voluntary segment disclosure: Evidence from Italian listed companies. European Accounting Review, 13(2), 319-340.

35. Scott, W. (1994). Incentives and disincentives for financial disclosure: Voluntary disclosure of defined benefit pension plan information by Canadian firms. The Accounting Review, 69(1), 26.

36. Shuaib, S. (1978). The Middle East: Accounting in Kuwait and Banker's View of Business Opportunities in the Area. The Journal of Accountancy, November pp.74-79.

37. Singhvi, S., \& Desai, H. (1971). An Empirical Analysis of the Quality of Corporate Financial Disclosure The Accounting Review 46(1), 129-138.

38. Street, D. L., \& Bryant, S. M. (2000). Disclosure level and compliance with IASs: A comparison of companies with and without U.S. listings and filings. The International Journal of Accounting, 35(3), 305.

39. Tower, G., Hancock, P., \& Taplin, R. H. (1999). A regional study of listed companies' compliance with international accounting standards. Accounting Forum, 23(3), 293-305.

40. Verrecchia, R. E. (1983). Discretionary Disclosure. Journal of Accounting \& Economics, 5(3), 179.

41. Wallace, R. S. O., \& Naser, K. (1995). Firm-Specific Determinants of the Comprehensiveness of Mandatory Disclosure in the Corporate Annual Reports of Firms Listed on the Stock Exchange of Hong Kong Journal of Accounting and Public Policy 14(4), 311-368.

42. Wallace, R. S. O., Naser, K., \& Mora, A. (1994). The relationship between the comprehensiveness of corporate annual reports and firm characteristics in Spain. Accounting and Business Research, 25(97), 41.

43. Watts, R., \& Zimmerman, J. (1983). Agency Problems, Auditing and the Theory of the Firm: Some Evidence. Journal of Law and Economics, 1226, 613-634. 


\section{APPENDIX}

\begin{tabular}{|c|c|c|c|}
\hline \multicolumn{4}{|c|}{ Appendix A: IAS 14 Disclosure Checklist ${ }^{1}$} \\
\hline $\begin{array}{l}\text { Source of } \\
\text { Info. }\end{array}$ & $\begin{array}{l}\text { Item } \\
\text { No. }\end{array}$ & Disclosure Requirements & Score* \\
\hline IAS 14 & & Segment Reporting & \\
\hline Para. 51 & 1 & $\begin{array}{l}\text { For each reportable segment, an enterprise should disclose the segment revenue from sales to } \\
\text { external customers }\end{array}$ & \\
\hline Para. 51 & 2 & $\begin{array}{l}\text { For each reportable segment, an enterprise should disclose the segment revenue from transactions } \\
\text { with other segments }\end{array}$ & \\
\hline Para. 52 & 3 & $\begin{array}{l}\text { For each reportable segment, an enterprise should disclose segment result from continuing } \\
\text { operations separately from segment result from discontinued operations }\end{array}$ & \\
\hline Para. 55 & 4 & $\begin{array}{l}\text { An enterprise should disclose the total carrying amount of segment assets for each reportable } \\
\text { segment }\end{array}$ & \\
\hline Para. 56 & 5 & An enterprise should disclose segment liabilities for each reportable segment & \\
\hline Para. 57 & 6 & $\begin{array}{l}\text { An enterprise should disclose the total cost incurred during the period to acquire segment assets } \\
\text { that are expected to be used during more than one period (property, plant, equipment, and } \\
\text { intangible assets) for each reportable segment }\end{array}$ & \\
\hline Para. 58 & 7 & $\begin{array}{l}\text { An enterprise should disclose the total amount of expense included in segment result for } \\
\text { depreciation and amortisation of segment assets for the period for each reportable segment }\end{array}$ & \\
\hline Para. 61 & 8 & $\begin{array}{l}\text { For each reportable segment, an enterprise should disclose the total amount of significant non- } \\
\text { cash expenses (other than depreciation and amortisation) that were included in segment expense }\end{array}$ & \\
\hline Para. 61 & 9 & $\begin{array}{l}\text { For each reportable segment, an enterprise should disclose aggregate of the entity's share of the } \\
\text { net profit or loss of associates, joint ventures, or other investments accounted for under the equity } \\
\text { method, if substantially all of those associates' (or joint ventures' or other investments') } \\
\text { operations are within that single segment }\end{array}$ & \\
\hline Para. 67 & 10 & $\begin{array}{l}\text { An enterprise should present a reconciliation between segment revenue and the enterprise's } \\
\text { revenue from external customers }\end{array}$ & \\
\hline Para. 67 & 11 & $\begin{array}{l}\text { An enterprise should present a reconciliation between segment result from continuing operations } \\
\text { and a comparable measure of the enterprise's operating profit or loss from continuing operations }\end{array}$ & \\
\hline Para. 67 & 12 & $\begin{array}{l}\text { An enterprise should present a reconciliation between segment result from discontinued } \\
\text { operations and the enterprise's profit or loss from discontinued operations }\end{array}$ & \\
\hline Para. 67 & 13 & An enterprise should present a reconciliation between segment assets and the enterprise's assets & \\
\hline Para. 67 & 14 & $\begin{array}{l}\text { An enterprise should present a reconciliation between segment liabilities and the enterprise's } \\
\text { liabilities }\end{array}$ & \\
\hline Para. 69 & & $\begin{array}{l}\text { If the enterprise's primary format for reporting segment information is business segments, the } \\
\text { following information should be disclosed: }\end{array}$ & \\
\hline $\begin{array}{l}\text { Para. } 69 \\
\text { (a) }\end{array}$ & 15 & $\begin{array}{l}\text { Disclose segment revenue from external customers, by geographical area, based on geographical } \\
\text { location of its customers, for each geographical segment whose revenue from sales to external } \\
\text { customers is } 10 \text { per cent or more of total enterprise revenue from sales to all external customers }\end{array}$ & \\
\hline $\begin{array}{l}\text { Para. } 69 \\
\text { (b) }\end{array}$ & 16 & $\begin{array}{l}\text { Disclose the total carrying amount of segment assets, by geographical location of assets, for each } \\
\text { geographical segment whose segment assets are } 10 \text { per cent or more of the total assets of all } \\
\text { geographical segments }\end{array}$ & \\
\hline $\begin{array}{l}\text { Para. } 69 \\
\text { (c) }\end{array}$ & 17 & $\begin{array}{l}\text { Disclose the total cost incurred during the period to acquire segment assets that are expected to be } \\
\text { used during more than one period (property, plant, equipment, and intangible assets), by } \\
\text { geographical location of assets, for each geographical segment whose segment assets are } 10 \text { per } \\
\text { cent or more of the total assets of all geographical segments }\end{array}$ & \\
\hline Para. 70 & & $\begin{array}{l}\text { If the enterprise's primary format of reporting segment information is geographical segments, the } \\
\text { enterprise should disclose the following segment information for each business segment whose } \\
\text { revenue from sales to external customers is } 10 \text { per cent or more of total entity revenue from sales } \\
\text { to all external customers whose segment assets are } 10 \text { per cent or more of the total assets of all } \\
\text { business segments: }\end{array}$ & \\
\hline $\begin{array}{l}\text { Para. } 70 \\
\text { (a) }\end{array}$ & 18 & Disclose segment revenue from external customers & \\
\hline $\begin{array}{l}\text { Para. } 70 \\
\text { (b) }\end{array}$ & 19 & Disclose the total carrying amount of segment assets & \\
\hline
\end{tabular}

${ }^{1}$ The official IASB volume for 2008 (IASB, 2008) was used to obtain details about each IAS 14 requirement. 


\begin{tabular}{|c|c|c|}
\hline $\begin{array}{l}\text { Para. } 70 \\
\text { (c) }\end{array}$ & 20 & $\begin{array}{l}\text { Disclose the total cost incurred during the period to acquire segment assets that are expected to be } \\
\text { used during more than one period (e.g. property, plant, equipment, and intangible assets) }\end{array}$ \\
\hline Para. 74 & & $\begin{array}{l}\text { If a business segment or geographical segment for which information is reported to the board of } \\
\text { directors and chief executive officer is not a reportable segment because it earns a majority of its } \\
\text { revenue from sales to other segments, but nonetheless its revenue from sales to external } \\
\text { customers is } 10 \text { per cent or more of total entity revenue from sales to all external customers, the } \\
\text { enterprise shall disclose: }\end{array}$ \\
\hline $\begin{array}{l}\text { Para. } \\
74(\text { a) }\end{array}$ & 21 & Disclose the fact that these circumstances exist \\
\hline $\begin{array}{l}\text { Para. } \\
\text { 74(b) }\end{array}$ & 22 & Disclose the amount of revenue from sales to external customers \\
\hline $\begin{array}{l}\text { Para. } \\
74(\mathrm{c})\end{array}$ & 23 & Disclose the amount of revenue from internal sales to other segments \\
\hline Para. 75 & 24 & An enterprise should disclose the basis of pricing inter-segment transfers \\
\hline Para. 75 & 25 & An enterprise should disclose any changes in the basis of pricing inter-segment transfers \\
\hline Para. 76 & 26 & $\begin{array}{l}\text { An enterprise should disclose changes in accounting policies adopted for segment reporting that } \\
\text { have a material effect on segment information }\end{array}$ \\
\hline Para. 76 & 27 & An enterprise should disclose a description of the nature of the change in accounting policies \\
\hline Para. 76 & 28 & An enterprise should disclose the reasons for the change in accounting policies \\
\hline Para. 76 & 29 & $\begin{array}{l}\text { An enterprise should disclose the fact that comparative information has been restated to account } \\
\text { for the change in accounting policies or that it is impracticable to do so }\end{array}$ \\
\hline Para. 81 & 30 & $\begin{array}{l}\text { An enterprise should disclose the types of products and service included in each reported business } \\
\text { segment }\end{array}$ \\
\hline Para. 81 & 31 & An enterprise should disclose the composition of each reported geographical segment \\
\hline \multicolumn{3}{|c|}{ Total Score for Compliance with IAS 14 Requirements } \\
\hline
\end{tabular}

* Scoring Procedure:

$1=$ Requirement is complied with

$0=$ Requirement is not complied with

$\mathrm{N} / \mathrm{A}=$ Requirement is not applicable 
NOTES 